Filosofi Ekonomi, Oleh: Jamaluddin

\title{
FILOSOFI EKONOMI SYARI'AH SEBAGAI LANDASAN PERBANKAN SYARI'AH
}

\author{
Jamaluddin ${ }^{*}$
}

\begin{abstract}
Abstrak
Sistem perbankan syari'ah dalam kerangka "dual banking system" (sistem perbankan ganda) antara konvensional dan syari'ah. perbankan konvensional dengan perbankan syari'ah adalah adanya larangan untuk membayar dan menerima bunga pada perbankan syari'ah. Secara filosofis dan prinsipil perbedaan keduanya sangat jelas. Bank syari'ah mengumpulkan pendapatanya melalui bagi hasil. Sedangkan Bank Konvensional menggantungkan pada bunga yang diperolehnya.
\end{abstract}

Kata Kunci: Filosofis, Perbangkan Syariah

\section{Pendahuluan}

Kelahiran (ilmu) Ekonomi Islam bukan sebagai respons atau sikap reaksioner terhadap fenomena ekonomi kapitalisme. Awal keberadaanya sama dengan awal keberadaan Islam di muka bumi ini, karena ekonomi Islam merupakan bagian integral yang tidak dapat dipisahkan dari Islam itu sendiri.

Islam yang diyakini sebagai jalan atau konsep hidup manusia, dapat dikatakan bahwa ekonomi Islam merupakan aktivitas agama atau ibadah dalam berekonomi. Islam sebagai agama yang syumul (komprehensif), artinya sempurna (kaffah) sesuai dengan al Qur'an surat al-Maidah 3, al-An'am 38, dan an-Nahl 89, sbb:

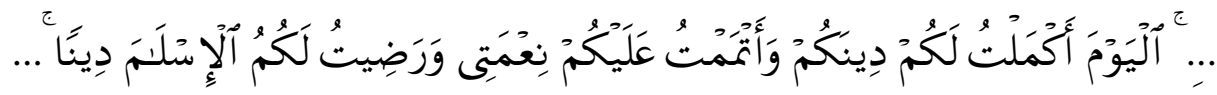

$$
\text { (المائدة : } 3 \text { (ائ) }
$$

* Dosen Tetap Fak. Syari'ah, Pemb. Rektor III IAIT Kediri, Dewan Pengawas Syari'ah (DPS) BPRS Tanmiyya Artha Kota Kediri \& Sekretaris I MUI Kota Kediri

Vol. 22 Nomor. 2 Juli 2011 
Terjemahnya: “... pada hari ini telah Ku-sempurnakan untuk kamu agamamu, dan telah Ku-cukupkan kepadamu nikmat-Ku, dan telah Ku-ridhai Islam itu jadi agama bagimu. ...”(QS. AlMaidah, 3) ${ }^{1}$

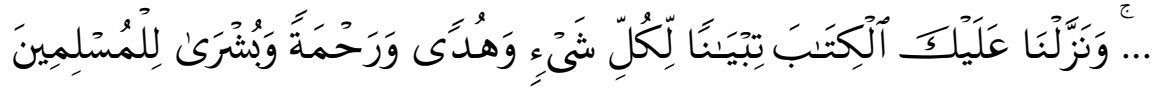

Terjemahnya: “... Kami turunkan kepadamu Al Kitab (Al Quran) untuk menjelaskan segala sesuatu dan petunjuk serta rahmat dan kabar gembira bagi orang-orang yang berserah diri. ..." (QS. An-Nahl, $89^{2}$

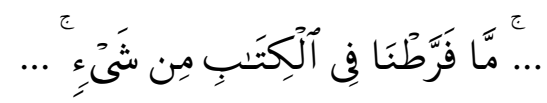

Terjemahnya: “... Tiadalah Kami alpakan sesuatupun dalam Al-Kitab, kemudian kepada Tuhanlah mereka dihimpunkan. ...” (QS. AlAn'am, 38) ${ }^{3}$

Sebagai konsekuensi logis, ekonomi merupakan bagian totalitas sistem Islam, landasan filosofis ekonomi Islam mencakup: tauhid rububiyah, khilafah, tazkiyah dan accountability. ${ }^{4}$ Proses penyucian (tazkiyah) selalu berkorelasi dengan ketenangan (internal harmony). Tanpa pretensi apologia, proses ini menjadikan sejarah abad ke 14 yang lalu sebagai titik awal pembangunan Islami. ${ }^{5}$

Pengembangan sistem perbankan syari' ah dalam kerangka " $d u a l$ banking system" (sistem perbankan ganda) antara konvensional dan syari'ah adalah kerangka Arsitektur Perbankan Indonesia, yang menghadirkan alternatif jasa perbankan yang semakin lengkap kepada masyarakat Indonesia tanpa terkecuali.

${ }^{1}$ Departemen Agama RI., Al Qur'an dan Terjemahnya, Insan Karya Indonesia, (Jakarta: 2004), h. 157.

${ }^{2}$ Departemen Agama RI., al Qur'an dan Terjemahnya, h. 415

${ }^{3}$ Departemen Agama RI., al Qur'an dan Terjemahnya, h. 192

4 Khursid Ahmad, Economic Developmen in an Islamic Framework, dalam Islamic Perspective (London: The Islamic Foundation, 1979), h. 223.

5 Anwar Ibrahim, Islam dan Pembangunan Ekonomi Umat, dalam Ainur R. Shopiaan, ed. Etika Ekonomi Politik:Elemen-elemen Strategis Pembangunan Mayarakat Islam, (Surabaya: Risalah Gusti, 1997), viii. 
Filosofi Ekonomi, Oleh: Jamaluddin

Sistem perbankan syari'ah dan konvensional secara sinergis mendukung mobilitas dana masyarakat secara lebih luas untuk meningkatkan kemampuan pembiayaan bagi sektor-sektor perekonomian nasional. Dengan SDM dan SDA bangsa Indonesia yang dimiliki, maka sangat berpeluang untuk menjadi platform pusat keuangan syari'ah (islamic financial). Indonesia sebagai pusat ekonomi syari'ah dunia, diharapkan akan membuka kesempatan yang lebih luas bagi sumber-sumber pembiayaan dari pasar keuangan syari'ah internasional.

Karakteristik sistem perbankan syari'ah adalah menonjolkan aspek keadilan dalam bertransaksi, investasi yang beretika, mengedepankan nilai kebersamaan dan persahabatan dalam berproduksi dan menghindari kegiatan spekulatif dalam bertransaksi keuangan, yang kemanfaatanya dapat dinikmati oleh semua pihak tanpa terkecuali. Sistem perbankan syari'ah adalah alternatif sistem perbankan yang saling menguntungkan kepada kedua belah pihak (nasabah dan bank) yang didukung oleh keanekaragaman produk dan skema keuangan yang lebih variatif, dilakukan sacara transparan, agar terdapat keadilan kedua belah pihak

Perbankan syari'ah merupakan alternatif sistem perbankan yang kredibel dan menjadi pilihan masyarakat Indonesia. Perbedaan utama antara perbankan syari'ah dan konvensional adalah terletak pada :

a. Jenis produk yang lebih beragam dan skema keuangan yang lebih variatif,

b. Pengelolaan dana masyarakat yang transparan, sehingga lebih adil bagi nasabah dan perbankan.

\section{Pengertian Bank dan Perbankan Syari'ah}

Perbankan adalah badan usaha yang menghimpun dana dari masyarakat dalam bentuk simpanan dan menyalurkanya kepada masyarakat dalam rangka meningkatkan taraf hidup rakyat banyak, dengan demikian kegiatan usaha bank adalah:
a. Penghimpunan Dana
b. Penyaluran Dana,
c. Jasa Keuangan Perbankan ${ }^{6}$

${ }^{6}$ Agustianto, Konsep Operasional Perbankan Syari'ah, dalam Training of Trainer (TOT) Perbankan Syari'ah Bank Indonesia Kediri, Zava Consulting, (Jakarta: 2007), h. 2

Vol. 22 Nomor. 2 Juli 2011 
Perbankan syari'ah adalah suatu sistem perbankan yang dikembangkan berdasarkan prinsip syari'ah. Sedangka prisnisp syari'ah adalah prinsip hukum Islam dalam kegiatan perbankan berdasarkan fatwa yang dikeluarkan oleh lembaga yang memiliki kewenangan dalam penetapan fatwa di bidang syari'ah (dalam hal ini Majelis Ulama Indonesia (MUI). ${ }^{7}$

Secara legal formal kehadiran perbankan syari'ah di Indonesia telah didukung oleh perangkat hukum yang kuat, yaitu Undang-undang:

1. UU Nomor 07 Tahun 1992 tentang Perbankan,

2. UU Nomor 10 Tahun 1998 tentang Perbankan,

3. UU Nomor 23 Tahun 1999 tentang Bank Indonesia,

4. UU Nomor 21 Tahun 2008 tentang Perbankan Syari' ah $^{8}$

Filosofi Perbedaan Bank Syari'ah dan Konvensional

\begin{tabular}{|l|l|l|l|}
\hline NO & \multicolumn{1}{|c|}{$\begin{array}{c}\text { ASPEK } \\
\text { (INDIKATOR) }\end{array}$} & \multicolumn{1}{|c|}{ BANK } & BANK SYARI'AH \\
\hline 01 & Insenti & Bunga & Bagi Hasil \\
\hline 02 & Landasan Hukum & Hukum Positif & $\begin{array}{l}\text { Syari'ah } \\
\text { Positif) }\end{array}$ \\
\hline 03 & Orientasi & Dunia & Dunia - Akhirat \\
\hline 04 & Kelembagaan & Pengawasan Komisaris & $\begin{array}{l}\text { Pengawas DPS dan } \\
\text { Komisaris }\end{array}$ \\
\hline 05 & $\begin{array}{l}\text { Laporan } \\
\text { Keuangan }\end{array}$ & Accrual Basis & Cash Basis \\
\hline 06 & Proyek & Halal, Haram, Syubhat & Hallal \\
\hline 07 & Misi Dakwah & $\begin{array}{l}\text { Tdk ada orientasi amar } \\
\text { ma'ruf nahi munkar }\end{array}$ & $\begin{array}{l}\text { Amar ma'ruf nahi } \\
\text { munkar }\end{array}$ \\
\hline 08 & Sumber Ajaran & Kapitalisme & $\begin{array}{l}\text { Al-Qur'an, al- } \\
\text { Hadits dan Ijtihad } \\
\text { Ulama }\end{array}$ \\
\hline 09 & Fungsi Uang & $\begin{array}{l}\text { Sbg komuditas dan } \\
\text { dijualbelikan }\end{array}$ & $\begin{array}{l}\text { Tidak } \\
\text { komuditas }\end{array}$ \\
\hline 10 & Inflansi mendorong & $\begin{array}{l}\text { Bagi hasil dan tdk } \\
\text { mendorong inflansi }\end{array}$ \\
\hline 11 & $\begin{array}{l}\text { Hubungan para } \\
\text { pihak }\end{array}$ & $\begin{array}{l}\text { Bunga mansi } \\
\text { Debitur-kreditur }\end{array}$ & $\begin{array}{l}\text { Kemitraan } \\
\text { harmonis }\end{array}$ \\
\hline 12 & $\begin{array}{l}\text { Resistensi thd } \\
\text { krisis }\end{array}$ & $\begin{array}{l}\text { Rawan dan tdk } \\
\text { resistensi thd krisis }\end{array}$ & $\begin{array}{l}\text { Lebih } \\
\text { menghadapi krisis }\end{array}$ \\
\hline
\end{tabular}

7 Abu Muhammad Dwiono Koesen al-Jambi, Selamat Tinggal Bank Konvensional, CV. Tifa Surya Indonesia, (Jakarta: 2009), h. 37

8 Abu Muhammad Dwiono Koesen al-Jambi, Selamat Tinggal Bank

Konvensional, h. 38 
Filosofi Ekonomi, Oleh: Jamaluddin

\begin{tabular}{|c|c|c|c|}
\hline 13 & Siklus & $\begin{array}{lr}\text { Terjadi } & \text { siklus } \\
\text { kedholiman: Nasabah, } \\
\text { Bank, BI, dan Rakyat }\end{array}$ & $\begin{array}{ll}\text { Tidak } & \text { siklus } \\
\text { kedholiman } & \end{array}$ \\
\hline 14 & Dampak & $\begin{array}{l}\text { Bisa menaikan harga } \\
\text { BBM, Litrik, Telp. dll. }\end{array}$ & $\begin{array}{l}\text { Tdk ada dampak } \\
\text { buruk (merecovery } \\
\text { ekonomi) }\end{array}$ \\
\hline 15 & Keberkahan & $\begin{array}{ll}\begin{array}{l}\text { Mendapat } \\
\text { (hadits Nabi) }\end{array} & \text { laknat }\end{array}$ & Mendapat barokah \\
\hline 16 & Produk & $\begin{array}{l}\text { Tdk ada jual beli, } \\
\text { ijarah dan qard hasan }\end{array}$ & Banyak poduk \\
\hline 17 & Spekulasi Valas & $\begin{array}{l}\text { Tdk. denga tegas } \\
\text { melarangnya }\end{array}$ & Melarang dg. trgas \\
\hline 18 & Hukum Syari'ah & Bunga Haram & $\begin{array}{l}\text { Semua produk dan } \\
\text { sistem halal }\end{array}$ \\
\hline 19 & $\begin{array}{ll}\text { Sektor } & \text { Moneter } \\
\text { dan Riil } & \\
\end{array}$ & Terpisah & Terkait erat \\
\hline 20 & $\begin{array}{l}\text { Akselarasi } \text { Arus } \\
\text { Barang }\end{array}$ & $\begin{array}{l}\mathrm{Krg} \text { berorientasi pd } \\
\text { akselerasi arus barang }\end{array}$ & $\begin{array}{l}\text { Mendorong } \\
\text { akselerasi arus } \\
\text { barang (sektor riil) }\end{array}$ \\
\hline 21 & $\begin{array}{l}\text { Penentuan } \\
\text { Bungan dan Bagi } \\
\text { Hasil }\end{array}$ & $\begin{array}{l}\text { Besar - kecilnya bunga } \\
\text { tergantung: } \\
\text { 1. Tingkat bunga yg } \\
\text { berlaku, } \\
\text { 2. Nominal deposito, } \\
\text { 3. Jangka wkt } \\
\text { deposito. }\end{array}$ & $\begin{array}{l}\text { Tdk ada bunga, } \\
\text { tergantung: } \\
\text { 1. Penadapatan } \\
\text { Bank } \\
\text { 2. Nisbah bagi } \\
\text { Hasil } \\
\text { 3. Jangka wkt dan } \\
\text { Nominal }\end{array}$ \\
\hline 22 & $\begin{array}{l}\text { Fungsi dan } \\
\text { Kegiatan Bank }\end{array}$ & $\begin{array}{l}\text { Intermediary unit, Jasa } \\
\text { keuangan }\end{array}$ & $\begin{array}{l}\text { Manager Investasi, } \\
\text { Investor Sosial, dan } \\
\text { Jasa Keuangan }\end{array}$ \\
\hline 23 & $\begin{array}{l}\text { Mekanisme dan } \\
\text { Obyek Usaha }\end{array}$ & Pro Maghrib * & Anti Maghrib * \\
\hline 24 & Resiko Usaha & $\begin{array}{l}\text { Resiko } \quad \text { Bank } r \text { tdk } \\
\text { terkait langsung dg } \\
\text { debitur, resiko debitur } \\
\text { tdk terkait langsung dg } \\
\text { bank }\end{array}$ & $\begin{array}{lr}\text { Dihadapi bersama } \\
\text { antara baka dg } \\
\text { nasabah, dg prinsip } \\
\text { keadilan } \\
\text { kejujuran. }\end{array}$ \\
\hline 25 & Negatif Spead & $\begin{array}{l}\text { Sangat mungkin } \\
\text { negative spread seperti } \\
\text { masa krisis yg lalu. }\end{array}$ & 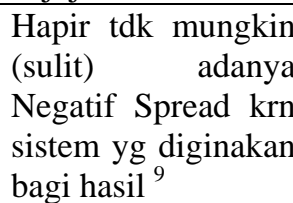 \\
\hline
\end{tabular}

Singkatan dari kata : MAGHRIB

${ }^{9}$ Agustianto, Konsep Operasional Perbankan Syari'ah, h. 4

Vol. 22 Nomor. 2 Juli 2011 
Filosofi Ekonomi, Oleh: Jamaluddin

1) Maysir, 2) Aniaya, 3) Ghoror, 4) Riba, Iktinas, 5) Bathil ${ }^{10}$

Dari uraian tabel di atas dapat disimpulkan bahwa perbedaan pokok antara perbankan konvensional dengan perbankan syari'ah adalah adanya larangan untuk membayar dan menerima bunga pada perbankan syari'ah. Secara filosofis dan prinsipil perbedaan keduanya sangat jelas. Bank syari'ah mengumpulkan pendapatanya melalui bagi hasil. Sedangkan Bank Konvensional menggantungkan pada bunga yang diperolehnya.

Bunga (riba nasi'ah) pada umumnya melakat pada aktivitas simpan-pinjam uang pada perbankan konvensional. Sedangkan pernbankan syari'ah tidak menempuh cara transaksi simpan-pinjam berbunga. Pinjaman hanya digunakan sebagai aktivitas sosial tanpa meminta imbalan, perbankan syari'ah keuntungan usahanya melalui kegiatan yang bebas riba.

\section{Sejarah Perbankan Syari'ah di Indonesia}

Sejarah perkembangan sistem perbankan syari'ah di Indonesia mencerminkan dinamika aspirasi dan keinginan dari masyarakat Indonesia itu sendiri untuk memiliki sebuah alternatif sistem perbankan yang adil, melalui penerapan sistem bagi hasil yang saling menguntungkan antara nasabah dan bank.

Rintisan praktek perbankan syari'ah dimulai pada awal tahun 1980-an, sebagai proses pencarian alternatif sistem perbankan yang diwarnai oleh prinsip-prinsip transparasi, berkeadilan, seimbang dan beretika dalam mewujudkan masyarakat yang sejahtera secara material maupun spiritual.

Pada tanggal 18 - 20 Agustus 1990, Majelis Ulama Indonesia (MUI) menyelenggarakan Lokakarya Bunga Bank dan Perbankan di Cisarua, Bogor, Jawa Barat. Hasil lokakarya tersebut kemudian dibahas lebih mendalam pada Musyawarah Nasional ke 4 MUI di Jakarta pada tanggal 22 - 25 Agustus 1990, yang menghasilkan anamat bagi pembentukan kelompok kerja pendirian bank Islam pertama di Indonesia. Dari hasil kerja Tim Perbankan tersebut lalu disepakati mendirikan PT Bank Muamalah Indinesia (BMI) hingga sekarang masih berdiri tegak.

10 Bank Indonesia Kediri, Taining of Trainer (TOT) Perbankan Syariah, tanggal 14-15 Nopember 2007 di Hotel Grand Surya Kediri. 
Filosofi Ekonomi, Oleh: Jamaluddin

\section{Fungsi Bank Syari’ah:}

1. Manajer Investasi, Bank syari'ah dapat mengelola investasi atas dana nasabah dengan menggunakan Akad Mudharabah (agen investasi)

2. Investor, Bank syari'ah dapat menginvestasikan dana yang dimilikinya maupun dana nasabah yang dipercayakan kepadanya dengan menggunakan alat investasi yang sesuai dengan Syari'ah. Keuntungan yang diperoleh dibagi secara proporsional sesuai dengan nisbah (hasil keuntungan) yang disepakati kedua belah pihak (antara bank dan pemilik dana).

3. Penyedia jasa keuangan dan lalu lintas pembayaran: Bank syari'ah dapat melakuan kegiatan jasa-jasa layanan perbankan lainya sepanjang tidak bertentangan dengan prinsip-prinsip syari'ah.

4. Bank syari'ah dapat memberikan layanan sosial dalam bentuk pengelolaan dana zakat, infaq dan shadaqah serta pinjaman kebajikan (qardhun hasan) sesusi dengan ketentuan yang berlaku ${ }^{11}$

\section{Karakteristik Bank Syari'ah}

Berangkat dari pijakan filosofis dan prinsip yang berlainan itu, maka bank syari'ah disamping memiliki perbedaan yang mendasar dengan bank konvensional, juga memiliki karakterisitik khusus yang menonjol, antara lain :

\section{a. Universal}

Bank syari'ah hadir untuk melayani setiap orang tanpa memandang perbedaan kemampuan ekonomi maupun perbedaan agama.

b. Adil

Bank syari'ah memberikan sesuatu hanya kepada yang berhak, dan memperlakukan sesuatu itu sesuai dengan posisinya dan melarang adanya unsur maysir (spekulasi/untung-umtungan), gharar (ketidak jelasan), haram dan riba.

c. Transparan

Aktifitas Bank Syari'ah sangat terbuka bagi seluruh lapisan masyarakat tanpa pandang strata ekonomi, agama, ras dan suku.

\section{d. Seimbang}

11 H. Suyono, Produk Bank Syari'ah \& Akutansi Bank Syari'ah, dalam TOT Perbankan Syari'ah - BI Kediri, Zava Consulting, tanggal 14-15 Nopember 2007, (Kediri: 2007), h. 2-3 
Filosofi Ekonomi, Oleh: Jamaluddin

Bank Syari'ah mengembangkan sektor keuangan melalui aktivitas perbakan syari'ah yang mencakup pengembangan sektor riil dan UMKM (Usaha Mikro Kecil dan Menengah).

\section{e. Maslahat}

Bank syari'ah hadir dengan misi membawa manfaat, maslahat, dan kebaikan bagi seluruh aspek kehidupan. masyarakat

\section{f. Variatif}

Produk Bank Syari'ah sangat bervariasi, banyak produk yang dihasilkan oleh bank syari'ah, seperti ; Giro Syari'ah, Deposito Syari'ah Murabahah, Salam, Istishna', Mudharabah, Musyarakah, Ijarah, Wakalah, Kafalah, Reksa Dana Syari'ah, Asuransi Syari'ah, Rahn, Obligasi Syari'ah, Letter of Credit (L/C) Inpor Syari'ah dan Expor Syari'ah, Akad Tabarru' pada Asuransi Syari'ah dan Reasuransi Syari'ah dan masih banyak produk syari'ah yang tidak dapat dilaksanakan pada Bank Konvensional.

\section{g. Fasilitas}

Bank Syari'ah memanjakan pelangganya dengan berbagai fasilitas, mulai dari penerimaan dan penyaluran Zakat, Infaq dan Shadaqah (ZIS), Wakaf, Dana Kebajikan (qard), juga memiliki fasilitas ATM, mobile banking, internet banking dan lain sebaginya.

\section{Penutup}

Semakin meluasnya penggunaan produk dan jasa perbankan syari'ah dalam berbagai aktivitas perekonomian, diyakini akan membantu terbentuknya stabilitas sistem keuangan dan terciptanya harmonisasi antar sektor keuangan dan sektor riil perekonomian.

Dengan demikian falsafah ekonomi syari'ah harus digunakan sebagai landasan perbankan syari'ah dengan mengedepankan al-Falah (kesejahteraan dunia dan akhirat) dengan konsep al-adalah (keadilan), tawazun (keseimbangan), dan al-maslahah (kemaslahatan).

Al-Adalah (keadilan) dalam rangka untuk menghindari : riba, maysir, ghoror, dholim, dan haram. Tawazun (keseimbangan) dalam rangka mencapai: riil-financial, ris-rutern, bisnis sosial, mental spiritual, dan pemanfaatan. Maslahah (kemaslahatan), dalam rangka untuk memelihara dan menjaga : imam dan taqwa, regenarsi, jiwa, harta, dan akal.

Tujuan utama konsep al Falah adalah kesuksesan yang hakiki, berupa tercapainya kesejahteraan di dunia dan akhirat, yang diartikan 
Filosofi Ekonomi, Oleh: Jamaluddin

tercapainya pemenuhan kebutuhan hidup di dunia (aspek ekonomi sosial) yang ditandai dengan semakin menyempitnya jurang pemisahan antara masyarakat yang mampu dan yang tidak/kurang mampu (kaya dan miskin), serta terpenuhinya kebutuhan dasar manusia (maslahat).

Kondisi tersebut di atas akan mengantar manusia pada tujuan akhir, yaitu kesejahteraan di akhirat yang berarti terpenuhinya kewajiban-kewajiban (acountalility) manusia sebagai khalifah di dunia yang mempunyai tugas utama memakmurkan bumi dan beribadah kepada Allah swt.

Ada 3 (tiga) pilar ekonomi syari'ah yang melatarbelakangi munculnya konsep falsafah ekonomi syari'ah sebagai landasan perbankan syari'ah, sbb :

1. Aktifitas ekonomi syari'ah yang berkeadilan dengan menghindarkan eksploitasi berkelebihan, exlusif, hoardings/unproductive, spekulatif, dan kesewang-wenangan.

2. Adanya keseimbangan aktivitas disektor riil-financial, pengelolaan risk-return, bisnis-sosial, aspek spiritual-material dan asas manfaatkelestarian lingkungan.

3. Orientasi pada kemaslahatan yang berarti melindungi keselamatan kehidupan beragama, proses regenerasi, serta perlindungan keselamatan jiwa, harta, dan akal.

Sementara konsep ekonomi syari'ah diilhami oleh 4 (empat) pondasi yang kuat, yaitu :

1. Ukhuwah : meletakkan tata hubungan bisnis dalam konteks Kebersamaan Universal untuk mencapai kesuksesan bersama,

2. Syari'ah: kaidah-kaidah hukum mu'amalah di bidang ekonomi yang membimbing aktivitas ekonomi sehingga selalu sesuai dengan syari'ah.

3. Akhlak: yang membimbing aktivitas ekonomi senantiasaa mengedepankan kebaikan cara mencapai tujuan.

4. Aqidah : taqwa kepada Allah swt. yang dapat menimbulkan kesadaran bahwa setiap aktivitas manusia memiliki pertanggungjawaban kepada Allah swt, sehingga akan menimbulkan integritas yang sejalan dengan prinsip tata kelola usaha yang baik dan benar (good corporate govermance) sesuai tuntunan syari'ah.

Vol. 22 Nomor. 2 Juli 2011 
Filosofi Ekonomi, Oleh: Jamaluddin

\section{DAFTAR KEPUSTAKAAN}

Abu Muhammad Dwiono Koesen al-Jambi, Selamat Tinggal Bank Konvensional, CV Tifa Surya Indonesia, Jakarta, 2009.

Agus Tianto, Konsep Operasional Perbankan Syari'ah, dalam Tarining of Trainer (TOT) Perbankan Syari'ah Bank Indonesia, Zava Colsolting, Jakarta, 2007.

Anwar Ibrahim, Islam dan Pembangunan Ekonomi Umat, dalam Ainur R. Shopiaan, ed Etika Ekonomi Politik: Elemen-elemen Strategis Pembangunan Masyarakat Islam, Risalah Gusti, Surabaya, 1997.

Buchari Alma dan Donni Juni Priansa, Manajemen Bisnis Syari'ah, Alfabeta, Bandung, 2009.

Bank Indonesia (BI) Training of Trainer (TOT) Perbankan Syari'ah, di Grand Surya Hotel Kediri, 2007.

Departemen Agama RI., Al-Qur'an dan Terjemahnya, CV Insan Karya Indonesia, Jakarta, 2004.

Himpunan Fatwa DSN MUI., Produk Perbankan Syari'ah, Gaung Persada, Jakarta, 2006.

A. Suyono, Produk Bank Syari'ah dan Akutansi Bank Syari'ah, dalam TOT - BI, Zava Consulting, Kediri, 2007.

Hirsanuddin, Hukum Perbankan Syari'ah di Indonesia, Pembiayaan Bisnis dengan Prinsip Kmitraan, Genta Press, Yogyakarta, 2008.

Khursid Ahmad, Economic Depelopmen in an Islamic Framework, dalam Islamic Perspective, The Islamic Foundation, London, 1979.

M. Umer Chapra dan Tariqullah Khan, Regulasi dan Pengawasan Bank Syari'ah, PT Bumi Aksara, Rawamangun Jakarta Utara, 2008.

Muhammad Syafi'i Antonio, Bank Syari'ah dari Teori ke Praktek, Gema Insani, Jakarta, 2001 